ISSN : 2303-1514 | E-ISSN : 2598-5949

\title{
EFFORTS TO IMPROVE LEARNING ACHIEVEMENT ON SOCIAL SCIENCES SUBJECT BY APPLYING ROLE PLAYING METHOD AT GRADE V OF ELEMENTARY SCHOOL
}

\author{
Eufrasia Jeramat ${ }^{1}$, Sufantiara Naming ${ }^{2}$, Valeria Suryani Kurnila ${ }^{3}$, Mikael Nardi ${ }^{4}$ \\ ${ }^{1,2,3,4}$ Prodi Pendidikan Matematika, FKIP Universitas Katolik Indonesia Santu Paulus, Ruteng \\ ${ }^{1}$ Eva.jeramat@gmail.com, ${ }^{2}$ Sufantiara.naming@gmail.com, \\ ${ }^{3}$ valeria.suryani@gmail.com, ${ }^{4}$ Mikaelnardi@unikastpaulus.ac.id
}

\section{UPAYA MENINGKATKAN PRESTASI BELAJAR DENGAN MENERAPKAN METODE ROLE PLAYING PADA MATA PELAJARAN IPS KELAS V SD}

\begin{tabular}{|c|c|}
\hline ARTICLE HISTORY & ABSTRACT \\
\hline $\begin{array}{l}\text { Submitted: } \\
\text { 14 Maret } 2021 \\
14^{\text {th }} \text { March } 2021\end{array}$ & $\begin{array}{l}\text { Abstract: This study aimed to improve students' learning achievement on social science subject } \\
\text { at grade V of SD Wae Rii by applying role playing method. The research was conducted in } \\
\text { elementary schools Kecamatan Wae Rii Langke Rembong in the academic year 2019/2020. The } \\
\text { method was classroom action research design and McTaggart Kemmis consisting of three } \\
\text { phases: planning, action and observation stage, and the stage of reflection. The subjects were } \\
30 \text { students at grade V of SD Wae Rii. Data were collected through observation and tests. The } \\
\text { instrument of this study were observation sheets and test questions. The results showed that } \\
\text { role playing method improved the students' learning achievement on social science subject at } \\
\text { grade V SD Wae Rii. The increase was evident from that many students achieved a minimum } \\
\text { completeness criteria (KKM). In pretreatment, } 8 \text { students achieved KKM (40\%); in cycle I } 14 \\
\text { students reached the KKM (70\%), in cycle II it increased to } 17 \text { students who reached the KKM } \\
\text { (85\%). Based on data analysis, it was concluded that role playing method improved students } \\
\text { learning achievement on social science subject at grade Vof SD Kecamatan Wae Rii Langke } \\
\text { Rembong the Academic Year 2019/2020. }\end{array}$ \\
\hline
\end{tabular}

Keywords: learning achievement of social science, role playing method

Accepted:

07 Agustus 2021

$07^{\text {th }}$ August 2021

Published:

27 Agustus 2021

$27^{\text {th }}$ August 2021

Abstrak: Penelitian ini bertujuan untuk meningkatkan prestasi belajar siswa kelas V SD IPS Wae Rii dengan menerapkan metode bermain peran. Penelitian ini dilaksanakan di SD Negeri Kecamatan Wae Rii Langke Rembong tahun ajaran 2019/2020. Metode yang digunakan adalah penelitian tindakan kelas dengan desain penelitian tindakan kelas dan McTaggart Kemmis yang terdiri dari tiga tahap yaitu tahap perencanaan, tahap tindakan dan observasi, dan tahap refleksi. Subjek penelitian adalah siswa kelas V SD Wae Rii yang berjumlah 20 siswa. Teknik pengumpulan data yang digunakan adalah observasi dan tes. Instrumen penelitian ini menggunakan lembar observasi dan soal tes. Hasil penelitian menunjukkan bahwa metode pembelajaran role playing dapat meningkatkan prestasi belajar siswa kelas $V$ SD IPS Wae Rii. Peningkatan itu terlihat dari banyaknya siswa yang mencapai kriteria ketuntasan minimal (KKM). Pada pratindakan KKM siswa yang mencapai 8 siswa (40\%), pada siklus I siswa yang mencapai KKM sebanyak 14 siswa (70\%), pada siklus II meningkat menjadi 17 siswa (85\%). Berdasarkan analisis data dapat disimpulkan bahwa proses pembelajaran dengan menggunakan metode role playing dapat meningkatkan prestasi belajar siswa kelas V SD IPS Kecamatan Wae Rii Kecamatan Langke Rembong Tahun 2019/2020.vb

Kata Kunci : prestasi belajar IPS, metode role playing

\section{CITATION}

Jeramat, E., Naming, S., Kurnila, V. S. \& Nardi, M. (2021). Efforts to Improve Learning Achievement on Social Sciences Subject by Applying Role Playing Method at Grade V of Elementary School. Primary: Jurnal Pendidikan Guru Sekolah Dasar, 10 (4), 1026-1037. DOI: http://dx.doi.org/10.33578/jpfkip.v10i4.8092. 


\section{PENDAHULUAN}

Pendidikan merupakan proses belajar anak. Dalam pelaksanaan pembelajaran di sekolah dasar, setiap pelajaran diajarkan sesuai dengan tujuannya masing-masing dalam mempersiapkan siswa terjun dalam masyarakat. Sebagai seorang pendidik, guru memiliki peran penting dalam proses pembelajaran. Menurut Syah (2011: 249) peran guru dalam pembelajaran "sebagai direktur belajar (director of learning), artinya setiap guru diharapkan untuk pandai-pandai mengarahkan kegiatan belajar siswa agar mencapai keberhasilan belajar sebagaimana yang telah ditetapkan dalam tujuan pembelajaran". Guru bertanggung jawab untuk mengembangkan segala potensi yang dimiliki siswanya. Siswa merupakan objek pendidikan yang dikenai perlakuan oleh guru dalam proses pembelajaran. Selanjutnya Djamarah (2005: 51), siswa adalah "unsur manusiawi yang penting dalam kegiatan interaksi edukatif".

Dalam pelaksanaan pembelajaran di sekolah dasar, setiap pelajaran diajarkan sesuai dengan tujuannya masing-masing dalam mempersiapkan siswa terjun dalam masyarakat. Ilmu pengetahuan sosial di sekolah dasar merupakan mata pelajaran yang memadukan sejumlah konsep pilihan dan cabang-cabang ilmu sosial dan ilmu lainnya serta diolah berdasarkan prinsip pendidikan dan ditarik untuk dijadikan program pengajaran pada tingkat persekolahan. Salah satu tujuan utama pembelajaran ilmu pengetahuan sosial adalah membina pengetahuan siswa tentang pengalaman manusia dalam kehidupan bermasyarakat pada masa lalu, sekarang, dan di masa yang akan datang.

Dalam kurikulum 2004 (Susanto, 2016: 32), ada beberapa Tujuan Pembelajaran IPS di SD, yaitu: (1) Mengembangkan pemahaman tentang konsep-konsep dasar ilmu-ilmu sosial melalui pendekatan pedagogis dan psikologis; (2) Mengembangkan kemampuan berpikir kritis, kreatif, inquiri, dan pemecahan masalah serta keterampilan sosial;
(3) Menanamkan kesadaran dan loyalitas terhadap sistem nilai dan norma-norma sosial; dan (4) Meningkatkan kemampuan berkolaborasi dan berkompetisi secara sehat dalam kehidupan masyarakat yang sarat dengan keanekaragaman, baik dalam skala nasional maupun internasional.

Dengan memperhatikan tujuan dari mata pelajaran Ilmu Pengetahuan Sosial maka seharusnya pembelajaran IPS harus dilaksanakan sebagai suatu kegiatan yang disenangi, menantang, dan bermakna bagi para peserta didik melalui penggunaan metode pembelajaran yang sesuai. Menurut Susanto (2016: 47) metode pembelajaran merupakan "cara/teknik yang digunakan oleh guru kepada siswa dalam menyajikan materi pembelajaran dalam sebuah proses pembelajaran agar tujuan pembelajaran yang sudah dirancang dapat tercapai" Pemilihan metode dan model pembelajaran merupakan satu komponen yang sangat penting dalam pelaksanaan pembelajaran. Penggunaan satu metode serta pemilihan metode pembelajaran yang kurang tepat dapat mengakibatkan pembelajaran menjadi membosankan dan menjadi kurang efektif (Djamarah \& Zain, 2010: 83).

Berdasarkan hasil observasi yang dilakukan peneliti, ditemukan bahwa pembelajaran IPS Kelas V masih bersifat teacher centered. Guru dominan menggunakan metode ceramah dalam menyampaikan materi pelajaran. Tujuan penggunaan metode ceramah ini yaitu untuk mengejar target materi pelajaran yang harus disampaikan, sehingga kedudukan siswa hanya sebagai penerima pelajaran. Guru tidak menggunakan media pembelajaran sehingga penyampaian materi menjadi abstrak. Selain itu, guru juga kurang memahami karakteristik siswa sehingga penggunaan metode pembelajaran sangatlah minim. Hal ini mengakibatkan pembelajaran Ilmu Pengetahuan Sosial cendrung membosankan dan kurang menarik perhatian para siswa sehingga berdampak pada prestasi belajar siswa yang cenderung rendah. Hal ini terbukti pada hasil nilai UAS siswa yang tidak 
mencapai KKM. KKM Mata Pelajaran IPS adalah 68. Berdasarkan studi pendahulu, dari 20 siswa hanya 8 siswa (40\%) yang mencapai KKM, yang belum mencapai KKM sebanyak 12 siswa (60\%). Hal tersebut menandakan ketuntasan belajar IPS belum maksimal. Materi IPS kelas $\mathrm{V}$ yang dirasa sulit yaitu perjuangan melawan penjajahan. Materi ini dirasa sulit karena berisi hafalan tentang tokoh-tokoh dan peristiwa-peristiwa yang terjadi pada masa lalu.

Agar pembelajaran IPS menjadi pembelajaran yang aktif dan menyenangkan, dapat dilakukan melalui berbagai cara. Salah satu cara yang cukup efektif adalah melalui penerapan metode pembelajaran role playing. Menurut Hamdayama (2016: 113) metode role playing adalah "suatu cara penguasaan bahanbahan pelajaran melalui pengembangan imajinasi dan penghayatan siswa". Pengembangan imajinasi dan penghayatan dilakukan siswa dengan memerankannya sebagai tokoh hidup atau benda mati. Role playing dapat menanamkan kemampuan bertanggung jawab dalam bekerja sama dengan orang lain, menghargai pendapat dan kemampuan orang lain dan belajar mengambil keputusan dalam hubungan kerja. Dengan role playing juga siswa yang awalnya pasif dapat aktif, sehingga siswa berminat lagi pada pembelajaran IPS. Diharapkan dengan meningkatnya minat siswa berdampak pada peningkatan prestasi belajar siswa. Hal ini sejalan dengan hasil penelitian yang dilakukan oleh Anisa Mutmainah (2017) bahwa penerapan metode Role Playing pada pembelajaran Ilmu Pengetahuan Sosial (IPS) dapat meningkatkan hasil belajar siswa kelas V SD Negeri 1 Ngerangan Bayat Klaten. Peningkatan hasil belajar siswa dapat dilihat dari nilai rata-rata posttest dan presentase ketuntasan belajar siswa dari pratindakan, Post test akhir siklus I dan posttest akhir siklus II. Nilai rata-rata siswa sebelum tindakan adalah 42, nilai rata-rata pada akhir siklus I adalah 67 dan nilai rata- rata pada akhir siklus II adalah 84. Pada kondisi awal belum ada siswa yang mencapai KKM dengan presentase ketuntasan belajar 0\%. Pada hasil akhir siklus I sebanyak 5 siswa atau $35,7 \%$ dan tes akhir siklus II yaitu 13 siswa atau $92,9 \%$.

Berdasarkan latar belakang tersebut, peneliti melakukan penelitian dengan judul "Upaya Meningkatkan Prestasi Belajar dengan Menerapkan Metode Role Playing Pada Mata Pelajaran IPS Kelas V SDI Wae Rii”.

\section{KAJIAN TEORI}

IPS merupakan salah satu mata pelajaran yang diberikan di SD yang mengkaji seperangkat peristiwa, fakta, konsep, dan generalisasi yang berkaitan dengan isu sosial. Menurut Sapriya (2012: 7), mata pelajaran IPS merupakan "sebuah nama mata pelajaran yang merupakan integrasi dari mata pelajaran sejarah, geografi, dan ekonomi serta mata pelajaran ilmu sosial lainnya". Melalui mata pelajaran IPS, anak diarahkan untuk dapat menjadi warga negara yang demokratis, bertanggung jawab, serta warga dunia yang cinta damai.

Menurut Sumaatmadja (Guanawan, 2011:19), Studi sosial bukan merupakan bidang keilmuan atau disiplin akademis, melainkan lebih merupakan suatu bidang pengkajian tentang gejala dan masalah sosial. Menurut Gunawan (2011: 36), Ilmu sosial adalah "suatu bahan kajian yang terpadu yang merupakan penyederhanaan, adaptasi, seleksi, dan modifikasi yang diorganisasikan dari konsep-konsep dan keterampilan Sejarah, Geografi, Sosiologi, Antropolgi, dan Ekonomi". Sedangkan menurut Somantri (Sapriya, 2012: 11) pendidikan IPS adalah "seleksi dari disiplin ilmu-ilmu sosial dan humaniora, serta kegiatan dasar manusia yang diorganisasikan dan disajikan secara ilmiah dan psikologis untuk tujuan pendidikan".

Berdasarkan penjelasan di atas, dapat disimpulkan bahwa antara bidang kajian studi sosial dengan ilmu-ilmu sosial tidaklah berbeda, yaitu sebagai suatu studi yang bidang kajiannya sama-sama mempelajari kehidupan individu dalam masyarakat walaupun 
penekannya berlainan. Dengan demikian ruang lingkup IPS pada dasarnya adalah mempelajari manusia pada konteks sosialnya atau manusia sebagai anggota masyarakat.dengan demikian ilmu sosial lebih bersifat teoritis-akademis, sedangkan studi sosial lebih bersifat praktispragmatis.

Tujuan pendidikan adalah untuk mengoptimalkan potensi yang ada dalam diri yang mengarah pada perubahan tingkah laku pada diri siwa menjadi lebih baik. Dalam proses pembelajaran menyangkut dua hal yakni proses belajar dan prestasi belajar. Menurut Hamalik (2004: 48), prestasi belajar adalah "perubahan tingkah laku yang diharapkan pada siswa setelah dilakukan proses pembelajaran". Prestasi belajar merupakan puncak dari suatu proses pembelajaran. Jadi setelah siswa menjalani proses pembelajaran di dalam kelas, akan terlihat hasil dari proses pembelajaran tersebut, berupa prestasi yang baik atau prestasi yang kurang baik. Lazimnya prestasi belajar di sekolah berupa angka atau nilai sebagai bukti penguasaan terhadap suatu bidang ilmu maupun mata pelajaran tertentu. Seperti yang dijelaskan Djamarah (2002: 21) bahwa prestasi belajar adalah hasil yang dicapai dan perwujudan prestasi dapat dilihat dengan nilai yang diperoleh dari setelah mengikuti tes. Lebih lanjut Tu'u (2004: 75) menyatakan bahwa: Prestasi merupakan hasil yang dicapai seseorang ketika mengerjakan tugas atau kegiatan tertentu. Prestasi akademik merupakan hasil yang diperoleh dari kegiatan pembelajaran di sekolah yang bersifat kognitif dan biasanya ditentukan melalui pengukuran dan penilaian. Prestasi belajar merupakan penguasaan terhadap mata pelajaran yang ditentukan lewat nilai atau angka yang diberikan guru.

Berdasarkan penjelasan di atas, dapat disimpulkan bahwa bahwa prestasi belajar adalah hasil dari sebuah proses belajar, yang di wujudkan dalam bentuk nilai sebagai bentuk penguasaan siswa terhadap mata pelajaran yang diperoleh setelah melewati tahap penilaian berupa tes atau ujian.

Role playing atau bermain peran adalah "metode pembelajaran yang merupakan bagian dari simulasi dan diarahkan untuk mengkreasi peristiwa sejarah, peristiwaperistiwa aktual, atau kejadian-kejadian yang mungkin muncul pada masa mendatang" (Sanjaya, 2013:161). Menurut Hamdayama (2016: 113), metode role playing adalah "suatu cara penguasaan bahan-bahan pelajaran melalui pengembangan imajinasi dan penghayatan siswa". Pengembangan imajinasi dan penghayatan dilakukan siswa dengan memerankannya sebagai tokoh hidup atau benda mati".

Dari pengertian di atas, dapat disimpulkan bahwa metode role playing merupakan salah satu metode pembelajaran yang dilaksanakan melalui pengembangan imajinasi dan penghayatan siswa.

\section{METODE PENELITIAN}

Jenis penelitian yang digunakan adalah penelitian tindakan kelas (PTK). Menurut Carr \& Kemiss (Kusumah \& Dwitagama, 2010: 8), penelitian tindakan kelas (PTK) adalah "suatu bentuk penelitian refleksi diri (self reflective) yang dilakukan oleh para partisipan dalam situasi sosial untuk memperbaiki rasionalitas dan kebenaran". Penelitian tindakan kelas merupakan penelitian yang dilakukan oleh guru di kelasnya, dimana guru melakukan suatu tindakan dengan tujuan meningkatkan kualitas mengajarnya.

Desain penelitian yang digunakan dalam penelitian ini adalah merujuk pada model penelitian yang dikemukakan oleh Kemmis \& Taggart yang terdiri dari 3 tahap, yaitu tahap perencanaan, tahap tindakan dan observasi, dan tahap refleksi.

Penelitian ini dilakukan di SDI Wae Rii kecamatan Langke Rembong kabupaten Manggarai dengan jumlah 20 orang yang terdiri dari 13 orang perempuan dan 7 orang laki-laki. Subjek dalam penelitian ini adalah 
semua kelas V SDI Wae Rii, sedangkan objek penelitian ini adalah prestasi belajar IPS.

Teknik pengumpulan data yang digunakan dalam penelitian ini adalah teknik observas dan tes. Instrument penelitian menggunakan lembar observasi dan tes. Ada 2 lembar observasi yang digunakan yaitu lembar observasi untuk guru (mengamati keterampilan dan sikap guru selama proses pembelajaran dengan menerapan metode role playing) dan lembar observasi untuk siswa (mengamati sikap siswa selama proses pembelajaran dengan menerapakan metode roe playing). Adapun variabel dalam penelitian ini adalah metode role playing sebagai variabel bebas dan prestasi belajar siswa sebagai variabel terikat.
Menurut Kunandar (2013: 128-125), dalam pelaksanaan penelitian tindakan kelas ada dua jenis data yang dapat dikumpulkan oleh peneliti, yakni data kuantitatif (nilai hasil belajar siswa) dan data kualitatif (pemahaman peserta didik terhadap suatu mata pelajaran serta aktivitas siswa selama proses pembelajaran). Teknik analisis data meliputi analisis data observasi dan analisis data hasil tes.

1. Analisis data observasi

Analisis data sikap siswa menggunakan empat kategori, skor maksimal adalah 4 dan jumlah aspek yang diteliti yaitu 9 , sehingga skor keseluruhan adalah 4 x $9=36$. Kriteria penilaian dapat dilihat pada Tabel 1 .

Tabel 1. Kriteria penilaian

\begin{tabular}{ccc} 
No & Nilai angka & Keterangan \\
\hline 1 & $30-36$ & Amat baik \\
2 & $23-29$ & Baik \\
3 & $16-22$ & Cukup \\
4 & $9-15$ & Kurang
\end{tabular}

(Sumber: Sugiyono, 2011: 141-144)

Analisis data tentang aktivitas guru dalam pembelajaran IPS menggunakan model role playing menggunakan

$$
P=\frac{\text { jumlah skor yang dipi }}{\text { jumlah skor maksimi }} 100 \%
$$

Tabel 2. Taraf Penguasaan Kemampuan

\begin{tabular}{ccc} 
No & $\begin{array}{c}\text { Taraf penguasaan/ kemampuan } \\
(\mathbf{0 \% )})\end{array}$ & Kualifikasi \\
\hline 1 & $0-20 \%$ & Kurang sekali \\
2 & $21-40 \%$ & Kurang \\
3 & $41-60 \%$ & Cukup \\
4 & $61-80 \%$ & Baik \\
5 & $81-100 \%$ & Sangat baik \\
\hline
\end{tabular}

(Sumber: Nur, 2006: 137)

2. Analisis data hasil tes

Data hasil tes siswa dianalisis secara deskriptif kuantitatif yaitu dengan cara mencari nilai rerata tes setiap akhir siklus. Nilai yang diperoleh siswa dari hasil tes evaluasi kemudian dicari rerata dan dianalisis untuk mengetahui ada atau tidaknya peningkatan hasil belajar IPS siswa kelas V SDI Wae Rii setelah menggunakan metode pembelajaran role playing. Cara untuk mengetahui kenaikan hasil belajar adalah dengan menghitung rerata nilai siswa yang berhasil memperoleh nilai kriteria ketuntasan minimal (KKM) dari jumlah kelas itu. Untuk mencari perhitungan rerata secara klasikal dari sekumpulan nilai yang diperoleh, peneliti menggunakan rumus Mean (X), menurut Anas (2009: 81) sebagai berikut: 
Keterangan:

$$
M x \frac{\sum x}{N}
$$

dicari)

$$
\text { Mx = Mean (rata-rata yang }
$$

$\Sigma \mathrm{x}=$ jumlah semua nilai siswa

$\mathrm{N}=$ jumlah seluruh siswa

Cara untuk mengetahui kenaikan hasil belajar siswa adalah dengan menghitung presentasi siswa yang berhasil memperoleh nilai KKM atau di atas KKM dari jumlah siswa di kelas itu. Hasil tes siklus I akan dibandingkan dengan hasil tes siklus berikutnya. Jika terdapat kenaikan presentasi siswa yang lulus KKM pada siklus I sampai siklus II, maka dapat dikatakan pembelajaran menggunakan metode role playing meningkatkan prestasi belajar IPS siswa. Rumus untuk menghitung presentasi siswa yang lulus adalah sebagai berikut.

$$
P \frac{f}{N} \times 100 \%
$$

Keterangan :

P: angka persentase yang dicari

$f$ : frekuensi yang sedang dicari presentasinya (dalam hal ini adalah jumlah siswa yang mencapai nilai KKM)

$\mathrm{N}$ :jumlah frekuensi/ banyaknya individu dalam subjek penelitian/Jumlah seluruh siswa.

Setelah mencari rerata dan persentase ketuntasan siswa, untuk menentukan klasifikasi hasil belajar yaitu dengan kriteria penilaian kecakapan akademik maka terlebih dahulu dikonsultasikan dengan SDI Wae Rii. Standar ketuntasan komponen kecakapan akademik tersebut bersifat tentatif dalam arti sekolah dapat menentukan standar ketuntasan yang berbeda sesuai dengan target maupun karakteristik sekolah yang bersangkutan.Kriteria tingkat keberhasilan

\begin{tabular}{|c|c|c|}
\hline No & Interval & Klasifikasi \\
\hline 1 & $01-50$ & Kurang \\
\hline 2 & $51-67$ & Cukup Baik \\
\hline 3 & $68-84$ & Baik \\
\hline 4 & $85-100$ & Sangat baik \\
\hline
\end{tabular}
belajar siswa dapat dilihat pada Tabel 3 .

Tabel 3. Kriteria Tingkat Keberhasilan Belajar Siswa

\section{HASIL DAN PEMBAHASAN DESKRIPSI AWAL PRA TINDAKAN}

Kondisi awal sikap siswa kelas V dalam pembelajaran IPS di SDI Wae Rii yaitu rendahnya partisipasi siswa dalam proses pembelajaran, hal ini ditandai sedikit siswa yang menjawab pertanyaan yang diberikan oleh guru, siswa terkadang jenuh ketika mendengarkan penjelasan dari guru yang cenderung menggunakan metode ceramah. Dalam pembelajaran guru belum pernah menggunakan metode role playing, guru kebanyakan menggunakan metode ceramah, diskusi, dan penugasan. Sehingga siswa kurang terlibat aktif dalam pembelajaran.

Prestasi belajar IPS siswa kelas V SDI Wae Rii masih sangat rendah, hal ini dapat dilihat dari nilai pra tindakan yang diperoleh dari nilai ujian akhir semester I (UAS) siswa. Dari hasil nilai UAS diketahi dari 20 siswa yang berhasil mencapai KKM hanya 8 siswa (40\%) sedangkan yang belum tuntas sebanyak 12 siswa (60\%) dapat dilihat pada Tabel 4.

Tabel 4. Hasil belajar IPS Pra tindakan (Nilai UAS)

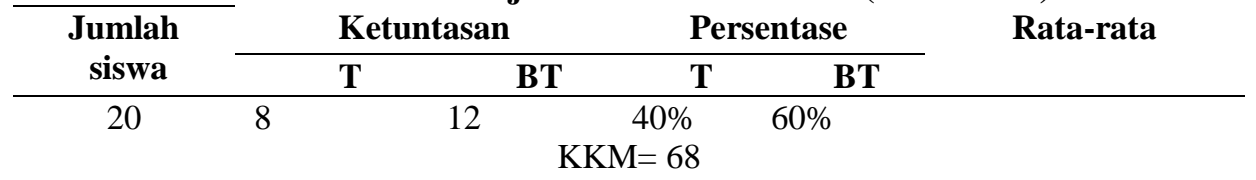




\section{PRIMARY: JURNAL PENDIDIKAN GURU SEKOLAH DASAR VOLUME 10 NOMOR 4 AGUSTUS 2021 \\ ISSN : 2303-1514 | E-ISSN : 2598-5949 \\ DOI : http://dx.doi.org/10.33578/jpfkip.v10i4.8092 \\ https://primary.ejournal.unri.ac.id/index.php/JPFKIP}

\section{PELAKSANAAN TINDAKAN}

Siklus I

Pada siklus I kegiatan Pembelajaran dimulai dari tahap perencanaan, pelaksaan dan observasi. Kegiatan pembelajaran pada siklus I dilaksanakan dalam dua pertemua yakni pertemuan pertama dan kedua dengan menggunakan metode role playing.

Hasil pelaksaan tindakan pada siklus I dapat di lihat pada Tabel 5.

Tabel 5. Sikap Siswa Dalam Pembelajaran IPS Pada Siklus I

\begin{tabular}{|c|c|c|c|c|c|c|c|c|c|c|c|c|}
\hline \multirow[t]{2}{*}{ No } & \multirow{2}{*}{$\begin{array}{l}\text { Nama } \\
\text { siswa }\end{array}$} & \multicolumn{9}{|c|}{ Aspek } & \multirow[t]{2}{*}{ Skor } & \multirow[t]{2}{*}{ Kriteria } \\
\hline & & 1 & 2 & 3 & 4 & 5 & 6 & 7 & 8 & 9 & & \\
\hline 1 & $A A D$ & 2 & 3 & 2 & 3 & 3 & 4 & 3 & 4 & 3 & 27 & $B$ \\
\hline 2 & $C A J$ & 3 & 4 & 3 & 3 & 4 & 2 & 3 & 3 & 4 & 29 & $B$ \\
\hline 3 & $E W$ & 4 & 3 & 3 & 3 & 4 & 3 & 4 & 3 & 3 & 30 & $A$ \\
\hline 4 & $F V N$ & 3 & 4 & 3 & 2 & 3 & 3 & 4 & 2 & 3 & 24 & $B$ \\
\hline 5 & $F F W$ & 3 & 4 & 3 & 3 & 3 & 3 & 3 & 3 & 3 & 28 & $B$ \\
\hline 6 & $F B$ & 3 & 3 & 2 & 2 & 2 & 2 & 2 & 2 & 2 & 20 & $C$ \\
\hline 7 & $F P E$ & 4 & 3 & 4 & 4 & 3 & 3 & 3 & 4 & 4 & 32 & $A$ \\
\hline 8 & $K D C A$ & 3 & 3 & 2 & 3 & 3 & 3 & 3 & 3 & 3 & 26 & $B$ \\
\hline 9 & $K N R$ & 3 & 3 & 3 & 3 & 2 & 3 & 3 & 3 & 3 & 26 & $B$ \\
\hline 10 & $K M T$ & 3 & 2 & 3 & 2 & 2 & 2 & 2 & 2 & 2 & 20 & $C$ \\
\hline 11 & $L S B$ & 2 & 3 & 3 & 2 & 3 & 2 & 2 & 2 & 2 & 21 & C \\
\hline 12 & $L N B$ & 3 & 3 & 2 & 2 & 2 & 3 & 3 & 2 & 2 & 22 & $C$ \\
\hline 13 & $M S T$ & 2 & 2 & 4 & 4 & 3 & 4 & 3 & 3 & 3 & 27 & $B$ \\
\hline 14 & $R E P$ & 4 & 4 & 3 & 3 & 4 & 4 & 3 & 4 & 4 & 33 & $A$ \\
\hline 15 & $S G$ & 3 & 3 & 3 & 3 & 3 & 3 & 3 & 3 & 3 & 27 & $B$ \\
\hline 16 & SRE & 3 & 4 & 4 & 4 & 3 & 4 & 4 & 4 & 4 & 34 & $A$ \\
\hline 17 & $T M H$ & 4 & 3 & 3 & 3 & 3 & 3 & 3 & 3 & 3 & 28 & $B$ \\
\hline 18 & $V O B$ & 2 & 3 & 3 & 2 & 3 & 3 & 3 & 4 & 3 & 26 & $B$ \\
\hline 19 & YOM & 3 & 2 & 3 & 2 & 3 & 2 & 2 & 3 & 2 & 22 & $C$ \\
\hline 20 & $Y R B$ & 3 & 3 & 2 & 2 & 2 & 3 & 2 & 2 & 2 & 21 & C \\
\hline
\end{tabular}

Keterangan: $\mathrm{A}=$ Amat Baik $\mathrm{B}=$ Baik $\mathrm{C}=$ Cukup

Berdasarkan data Tabel 5 sikap siswa kelas V SDI Wae Ri'i dapat dijelaskan sebagai berikut; siswa yang memiliki kriteria A (Amat Baik) sebanyak 4 orang (20\%), kriteria B (Baik) sebanyak 10 orang (50\%), kriteria $\mathrm{C}$ (Cukup) sebanyak 6 orang (30\%) dan tidak ada siswa yang memiliki kriteria $\mathrm{K}$ (Kurang). Berdasarkan data tersebut dapat disimpulkan hasil belajar ranah afektif siswa yang memenuhi kriteria $\geq \mathrm{B}$ sebanyak 14 orang (70\%). Siswa KMT, FB, YRB, LSB, YOM, dan LNB mencapai kriteria cukup karena kurang antusias dalam proses pembelajaran, tidak menjawab pertanyaan dari guru serta mengajukan pertanyaan tidak sesuai dengan pembelajaran yang dilaksanakan.

Setelah dilakukan tindakan selanjutnya pemberian tes. Tes ini digunakan untuk mengetahui seberapa besar pemahaman siswa mengenai materi yang disampaikan dengan metode role playing. Tes hasil belajar diperoleh data dilihat pada Tabel 6. 
Tabel 6. Hasil Belajar Siklus I

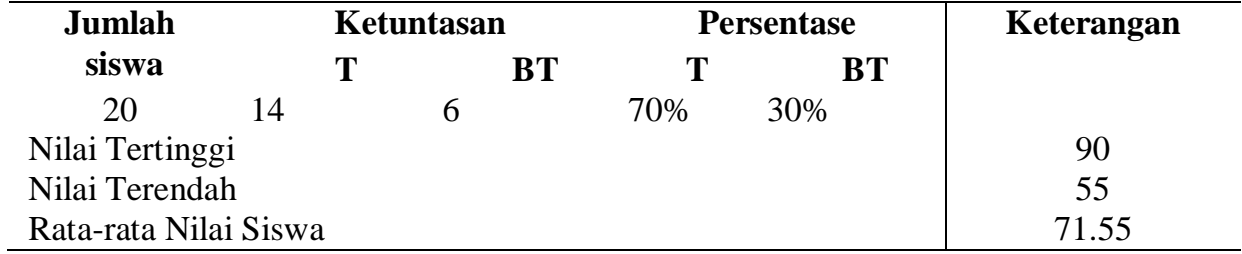

Berdasarkan data pada Tabel 6, siswa yang telah tuntas atau mencapai KKM (nilai $\geq$ 68) sebanyak 14 siswa (70\%), sedangkan yang belum tuntas sebanyak 6 siswa $\left(\begin{array}{ll}30 & \%\end{array}\right)$. Perbandingan hasil belajar IPS pra tindakan dengan siklus I dapat dilihat pada Tabel 7.

Tabel 7. Perbandingan Hasil Belajar Pra tindakan dan Siklus I

Ketuntasan

\begin{tabular}{lcll}
\hline & Pratindakan (\%) & \multicolumn{2}{c}{ Siklus I (\%) } \\
$\mathrm{T}$ & $\mathrm{BT}$ & $\mathrm{T}$ & $\mathrm{BT}$ \\
8 & 12 & 14 & 6 \\
$40 \%$ & $60 \%$ & $70 \%$ & $30 \%$ \\
$\mathrm{~T}=$ Tuntas & \multicolumn{3}{c}{$\mathrm{BT}=$ Belum Tuntas }
\end{tabular}

Berdasarkan data pada Tabel 7, diketahui bahwa sebelum menerapkan metode role playing siswa yang tuntas atau mencapai KKM $(\geq 68)$ sebanyak 8 orang $(40 \%)$ dan belum tuntas sebanyak 12 orang ( $60 \%$ ). Setelah dilakukan tindakan siklus I terjadi peningkatan. Jumlah siswa yang tuntas sebanyak 14 orang (70\%), sedangkan yang belum tuntas 6 orang (30\%). Kenaikan jumlah siswa yang tuntas sebelum dan setelah tindakan sebesar $30 \%$ (dari $40 \%$ menjadi $70 \%)$.

Tingkat prestasi belajar IPS siswa kelas V dapat diketahui dari klasifikasi kecakapan akademik. Klasifikasi hasil belajar IPS kelas V setelah tindakan dapat disajikan dalam Tabel 8 berupa frekuensi perolehan nilai dengan rentang nilai sebagai berikut.

Tabel 8. Hasil Belajar Siklus I

\begin{tabular}{cllll} 
No & \multicolumn{1}{c}{ Nilai } & Kategori & Frekuensi & Persentase (\%) \\
\hline $\mathbf{1}$ & $\mathbf{0 - 5 0}$ & Kurang & $\mathbf{0}$ & $\mathbf{0}$ \\
2 & $51-67$ & Cukup & 6 & 30 \\
3 & $68-84$ & Baik & 9 & 45 \\
4 & $85-100$ & Sangat Baik & 5 & 35 \\
\hline
\end{tabular}

\section{Refleksi Siklus I}

Berdasarkan hasil observasi yang dilakukan peneliti secara umum pelaksanaan pembelajaran menggunakan metode role playing pada mata pelajaran IPS siswa kelas V SDI Wae Ri'i sudah cukup baik. Jumlah siswa yang mencapai KKM kurang dari 75\%. Siswa yang mencapai KKM atau tuntas belajar sebanyak 14 siswa (70\%).
Setelah siklus I selesai, dilanjutkan dengan siklus II. Siklus II merupakan penyempurnaan dari siklus I. Konsep dan metode pembelajaran IPS pada siklus II sama dengan yang digunakan pada siklus I, akan tetapi telah disempurnakan berdasarkan hasil refleksi pada siklus I.

\section{Siklus II}




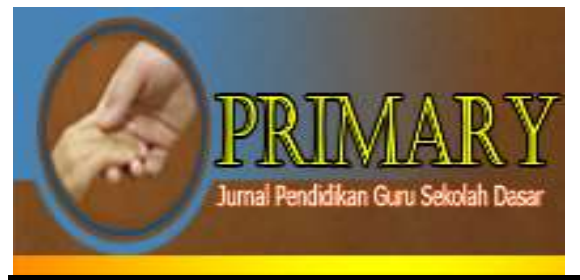

\author{
PRIMARY: JURNAL PENDIDIKAN GURU SEKOLAH DASAR \\ VOLUME 10 NOMOR 4 AGUSTUS 2021 \\ ISSN : 2303-1514 | E-ISSN : 2598-5949 \\ DOI : http://dx.doi.org/10.33578/jpfkip.v10i4.8092 \\ https://primary.ejournal.unri.ac.id/index.php/JPFKIP
}

Pada siklus II kegiatan Pembelajaran dimulai dari tahap perencanaan, pelaksaan dan observasi. Kegiatan pembelajaran pada siklus II dilaksanakan dalam dua pertemua yakni pertemuan pertama dan kedua dengan menggunakan metode role playing.

Hasil Pelaksanaan Tindakan Siklus II dilihat pada Tabel 9.

Tabel 9. Sikap siswa dalam pembelajaran IPS Siklus II

\begin{tabular}{|c|c|c|c|c|c|c|c|c|c|c|c|c|}
\hline \multirow[t]{2}{*}{ No } & \multirow{2}{*}{$\begin{array}{c}\text { Nama } \\
\text { siswa }\end{array}$} & \multicolumn{9}{|c|}{ Aspek } & \multirow[t]{2}{*}{ Skor } & \multirow[t]{2}{*}{ Kriteria } \\
\hline & & 1 & 2 & 3 & 4 & 5 & 6 & 7 & 8 & 9 & & \\
\hline 1 & $A A D$ & 2 & 3 & 2 & 3 & 3 & 4 & 3 & 4 & 3 & 27 & $B$ \\
\hline 2 & $C A J$ & 3 & 4 & 3 & 3 & 4 & 2 & 3 & 3 & 4 & 29 & $B$ \\
\hline 3 & $E W$ & 4 & 3 & 3 & 3 & 4 & 3 & 4 & 3 & 3 & 30 & $A$ \\
\hline 4 & $F V N$ & 3 & 4 & 3 & 2 & 3 & 3 & 4 & 2 & 3 & 24 & $B$ \\
\hline 5 & $F F W$ & 3 & 4 & 3 & 3 & 3 & 3 & 3 & 3 & 3 & 28 & $B$ \\
\hline 6 & $F B$ & 3 & 3 & 2 & 2 & 2 & 2 & 2 & 2 & 2 & 20 & $C$ \\
\hline 7 & $F P E$ & 4 & 3 & 4 & 4 & 3 & 3 & 3 & 4 & 4 & 32 & $A$ \\
\hline 8 & $K D C A$ & 3 & 3 & 2 & 3 & 3 & 3 & 3 & 3 & 3 & 26 & $B$ \\
\hline 9 & $K N R$ & 3 & 3 & 3 & 3 & 2 & 3 & 3 & 3 & 3 & 26 & $B$ \\
\hline 10 & $K M T$ & 3 & 2 & 3 & 2 & 2 & 2 & 2 & 2 & 2 & 20 & $C$ \\
\hline 11 & $L S B$ & 2 & 3 & 3 & 3 & 3 & 3 & 3 & 3 & 3 & 25 & $B$ \\
\hline 12 & $L N B$ & 4 & 4 & 3 & 4 & 3 & 3 & 3 & 3 & 3 & 30 & $A$ \\
\hline 13 & $M S T$ & 4 & 3 & 2 & 3 & 3 & 2 & 4 & 3 & 4 & 28 & $B$ \\
\hline 14 & $R E P$ & 4 & 4 & 3 & 3 & 4 & 4 & 3 & 4 & 4 & 33 & $A$ \\
\hline 15 & $S G$ & 3 & 3 & 3 & 3 & 3 & 3 & 3 & 3 & 3 & 27 & $B$ \\
\hline 16 & $S R E$ & 3 & 4 & 4 & 4 & 3 & 4 & 4 & 4 & 4 & 34 & $A$ \\
\hline 17 & $T M H$ & 4 & 4 & 4 & 3 & 3 & 3 & 3 & 3 & 4 & 31 & $B$ \\
\hline 18 & $V O B$ & 2 & 3 & 3 & 2 & 3 & 3 & 3 & 4 & 3 & 26 & $B$ \\
\hline 19 & $Y O M$ & 3 & 3 & 3 & 3 & 3 & 3 & 3 & 3 & 4 & 28 & $C$ \\
\hline 20 & $Y R B$ & 3 & 3 & 2 & 2 & 2 & 3 & 2 & 2 & 2 & 21 & $C$ \\
\hline
\end{tabular}

Keterangan A=Amat Baik, $B=B a i k, C=C u k u p$

Berdasarkan data pada Tabel 9 sikap siswa kelas V SDI Wae Ri'i dapat dijelaskan, siswa yang memiliki kriteria A sebanyak 6 orang $(30 \%)$, kriteria B sebanyak 11 orang (55\%), kriteria C sebanyak 3 orang (15\%) dan tidak ada siswa yang memiliki kriteria K. Berdasarkan data tersebut dapat disimpulkan hasil belajar ranah afektif siswa yang memenuhi kriteria $\geq \mathrm{B}$ sebanyak 17 orang $(85 \%)$. Siswa KMT, FB, dan YRB mencapai kriteria cukup karena kurang berantusias dalam proses pembelajaran, tidak menjawab pertanyaan dari guru serta mengajukan pertanyaan tidak sesuai dengan pembelajaran yang dilaksanakan.

Setelah dilakukan tindakan selanjutnya pemberian tes. Tes ini digunakan untuk mengetahui seberapa besar pemahaman siswa mengenai materi yang disampaikan dengan metode role playing. Tes hasil belajar diperoleh data dilihat pada Tabel 10 .

Tabel 10 Hasil Belajar Siklus II

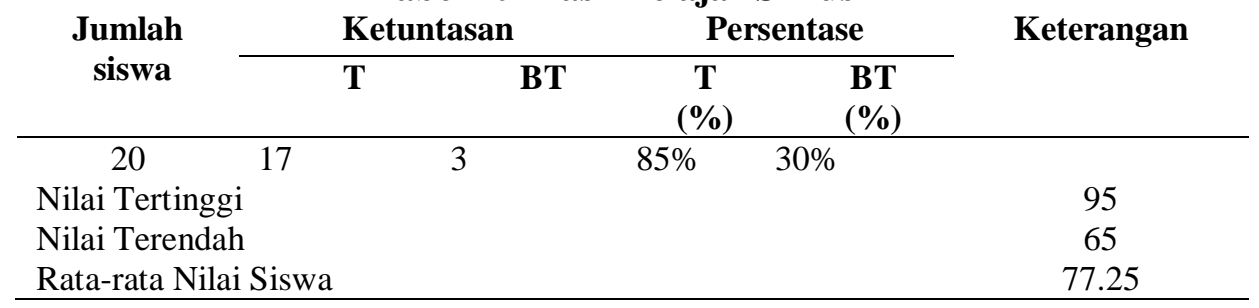


Dari Tabel 10, diketahui siswa yang telah tuntas atau mencapai KKM (nilai $\geq 68$ ) sebanyak 17 siswa (85\%), sedangkan yang belum tuntas sebanyak 3 siswa (15\%).

\begin{tabular}{cllll} 
No & \multicolumn{1}{c}{ Nilai } & \multicolumn{1}{c}{ Kategori } & Frekuensi & \multicolumn{1}{c}{ Persentase (\%) } \\
\hline $\mathbf{1}$ & $\mathbf{0 - 5 0}$ & Kurang & $\mathbf{0}$ & $\mathbf{0}$ \\
2 & $51-67$ & Cukup & 3 & 15 \\
3 & $68-84$ & Baik & 11 & 55 \\
4 & $85-100$ & Sangat Baik & 6 & 30 \\
\hline
\end{tabular}

Berdasarkan data hasil belajar IPS Siklus II, diketahui bahwa siswa yang memiliki nilai 51-67 sebanyak 3 orang (15\%). Siswa yang memiliki nilai $68-84$ sebanyak 11 orang (55\%) dan yang memiliki nilai $85-100$ sebanyak 6 orang $(30 \%)$. Dari data tersebut diketahui bahwa siswa kelas $\mathrm{V}$ yang sudah memenuhi kriteria ketuntasan minimal (KKM) yang mendapat nilai $\geq 68$ dan mencapai kriteria sikap "baik" terdapat 17 siswa $(85 \%)$.

Berdasarkan data tersebut dapat disimpulkan bahwa dengan menerapkan metode role playing dapat meningkatkan prestasi belajar siswa.

\section{Refleksi Siklus II}

Berdasarkan hasil observasi dan tes hasil belajar yang sudah dilakukan pada siklus II diketahui bahwa sikap siswa dalam pembelajaran meningkat dibandingkan dengan pembelajaran IPS pada siklus sebelumnya. Perhatian siswa terhadap penjelasan guru lebih fokus. Siswa berani bertanya, dan aktif menjawab pertanyaan yang diberikan guru. Siswa lebih disiplin, bersemangat dan bertanggung jawab terhadap tugas yang diberikan.Berikut perbandingan sikap siswa siklus I dan siklus II dilihat pada Tabel 12

Tabel 12. Perbandingan Sikap siswa dalam Pembelajaran IPS Siklus I dan II

\begin{tabular}{lll} 
Kriteria Sikap & Siklus I & Siklus II \\
\hline Amat Baik (A) & $4(20 \%)$ & $6(30 \%)$ \\
Baik (B) & $10(50 \%)$ & $11(55 \%)$ \\
Cukup (C) & $6(30 \%)$ & $3(15 \%)$ \\
Kurang (K) & $0(0 \%)$ & $0(0 \%)$
\end{tabular}

Berdasarkan hasil observasi yang terdapat dalam Tabel 12 adanya peningkatan sikap siswa dalam pembelajaran IPS pada siklus I ke siklus II. Pada siklus I siswa yang memperoleh nilai $\geq \mathrm{B}$ sebanyak 14 siswa (70\%), sementara pada siklus II siswa yang memperoleh nilai $\geq \mathrm{B}$ sebanyak 17 siswa (85\%). Terjadi peningkatan $15 \%$.

Berdasarkan hasil tes siklus II hasil belajar ranah kognitif setelah menggunakan metode pembelajaran role playing mengalami peningkatan. Hasil tindakan pada siklus II berupa tes hasil belajar menunjukkan bahwa 17 siswa (85\%) sudah tuntas atau memiliki nilai sama atau diatas kriteri ketuntasan minimal $(\mathrm{KKM}) \geq 68$. Sedangkan 3 siswa $(15 \%)$ memiliki nilai kurang dari KKM $(<68)$.

Berikut Tabel perbandingan hasil belajar pra tindakan, Siklus I, dan Siklus II dilihat pada Tabel 13. 
Tabel 13. Perbandingan hasil belajar Pra Tindakan, Siklus I dan Siklus II Ketuntasan

\begin{tabular}{|c|c|c|c|c|c|}
\hline \multicolumn{2}{|c|}{ Pra Tindakan } & \multicolumn{2}{|c|}{ Siklus I } & & Siklus II \\
\hline $\mathrm{T}$ & BT & $\mathrm{T}$ & BT & $\mathrm{T}$ & BT \\
\hline 8 & 12 & 14 & 6 & 17 & 3 \\
\hline $40 \%$ & $60 \%$ & $70 \%$ & $30 \%$ & $85 \%$ & $15 \%$ \\
\hline
\end{tabular}

Keterangan: $\mathbf{T}=$ Tuntas, $\mathrm{BT}=$ Belum Tuntas

Berdasarkan Tabel 13, diketahui bahwa jumlah siswa yang mencapai KKM mengalami peningkatan. Pada pra tindakan siswa yang tuntas ada 8 siswa (40\%), pada siklus I mengalami peningkatan menjadi 14 siswa (70\%), kemudian pada siklus II meningkat menjadi 17 siswa $(85 \%)$. Pada pra tindakan siswa yang belum tuntas 12 siswa $(60 \%)$, pada siklus I siswa yang belum tuntas 6 siswa (30\%), sedangkan pada siklus II siswa yang belum tuntas mengalami penurunan yaitu 3 siswa (15\%).

\section{PEMBAHASAN}

Berdasarkan hasil penelitian diketahui bahwa terjadi peningkatan prestasi belajar siswa pada siklus I ke siklus II yaitu pada siklus I yang mencapai sikap kriteria amat baik dan baik sebanyak 14 siswa (70\%), sedangkan siswa yang mencapai sikap kriteria cukup sebanyak 6 siswa (30\%). Pada siklus II banyak siswa yang memiliki kriteria amat baik dan baik meningkat menjadi 17 siswa (85\%), sedangkan siswa yang memiliki kriteria cukup mengalami penurunan yaitu 3 orang (15\%).Sedangkan

Pada siklus I sikap siswa yang meliputi aspek 1-9, dan penilaian siswa dalam pembelajaran dikatakan baik, siswa yang memperoleh nilai kategori baik dan amat baik sebanyak 14 siswa (70\%). Pada siklus II terjadi peningkatan sikap siswa dalam pembelajaran. Siswa lebih menyukai pembelajaran IPS, aktif menanggapi pernyataan guru dan aktif menjawab pertanyaan untuk memperdalam pemahaman siswa. Siswa yang memperoleh nilai kategori amat baik dan baik pada siklus II sebanyak 17 siswa $(85 \%)$.

Berdasarkan tes hasil belajar IPS menggunakan metode role playing mengalami peningkatan jumlah siswa yang tuntas atau memenuhi KKM. Hasil penelitian pada siklus I terjadi peningkatan hasil belajar siswa sebesar $30 \%$ (dari pra tindakan $40 \%$ menjadi $70 \%$ ), sedangkan siswa yang belum tuntas mengalami penurunan sebesar 30\% (dari pra tindkan $60 \%$ menjadi $30 \%$ ). Jumlah siswa yang belum tuntas pada siklus I sebanyak 6 orang $(30 \%)$ karena memiliki nilai $<68$. Siswa yang belum tuntas yaitu KMT, FB, YRB, LSB, YOM, dan LNB. Hasil belajar IPS siswa yang rendah disebakan perhatian siswa terhadap pembelajaran IPS kurang fokus dan keaktifan siswa dalam pembelajaran rendah (cenderung pasif).

Pada siklus II peningkatan hasil belajar sebesar 15\% (dari siklus I 70\% menjadi 85\%). Siswa yang tuntas meningkat, siswa yang mencapai KKM sebanyak 17 siswa (85\%), sedangkan siswa yang belum tuntas ada 3 siswa (15\%), terdiri dari 2 orang laki-laki dan 1 orang perempuan, yaitu FB, YRB, dan KMT. Melihat hasil tersebut guru kelas $\mathrm{V}$ perlu mengadakan pendekatan dan bimbingan khusus agar kedua siswa tersebut memperoleh hasil belajar IPS yang baik.

Hasil penelitian dapat disimpulkan bahwa penggunaan metode role playing dikatakan berhasil karena dapat meningkatkan sikap siswa dan hasil belajar siswa. Hal ini sejalan dengan pendapat Etin, S (2008: 14) bahwa penggunaan metode pembelajaran role playing pada mata pelajaran IPS tepat karena ciri khas pembelajaran pendidikan IPS adalah menekankan pada aspek pendidikan, yaitu siswa diharapkan memperoleh pemahaman konsep dan mengembangkan serta melatih sikap, nilai, moral, dan keterampilannya berdasarkan konsep yang telah dimilikinya. Proses pembelajaran yang digunakan pada 
penelitian ini mendorong siswa untuk berpartisipasi aktif dalam pembelajaran. Dalam pelaksanaan pembelajaran dengan menerapakan metode role playing ini guru diharapkan mampu mengelola kelas dengan baik agar semua siswa terlibat secara aktif dalam proses pembelajaran. Misalnya meminta semua siswa untuk berpartipasi dengan memberi pertanyaan ataupun pada saat mempresentasikan hasil diskusi. Atau dengan kata lain guru tidak hanya monoton pada siswa yang memiliki kemampuan tinggi saja, melainkan lebih diarahkan agar seluruh siswa dapat terlibat secara aktif sehingga tujuan pembelajaran dapat tercapai. Selain itu, pembagian kelompok juga harus bersifat heterogen, dalam arti bahwa dalam satu kelompok usahakan terdiri dari siswa yang memiliki latar belakang berbeda baik dari segi kemampuan, ataupun suku.

\section{SIMPULAN}

Berdasarkan hasil penelitian dan pembahasan, dapat disimpulkan bahwa proses pembelajaran menggunakan metode pembelajaran role playing dapat meningkatkan prestasi belajar siswa. Hal tersebut dibuktikan dengan meningkatnya jumlah siswa yang mencapai KKM, siklus I sebanyak $70 \%$ dan siklus II sebanyak $85 \%$ terjadi peningkatan $15 \%$. Keberhasilan tersebut diperoleh dengan menerapkan metode pembelajaran role playing dengan langkah menyampaikan cerita pengantar, pemilihan penonton dan pemain, menata panggung, permainan, diskusi, permainan berikutnya, diskusi lebih lanjut dan generalisasi. Sikap siswa terhadap pembelajaran IPS meningkat yang ditunjukkan dari siswa yang memiliki kategori nilai amat baik dan baik pada siklus I sebanyak 14 siswa (70\%) dan siklus II sebanyak 17 siswa (85\%), terjadi peningkatan $15 \%$. Sikap siswa dalam pembelajaran IPS sudah aktif bertanya dan menyatakan pendapat serta memiliki tanggung jawab terhadap tugas-tugas yang diberikan guru.

\section{REKOMENDASI}

Semoga penelitian ini bermanfaat bagi guru untuk meningkatkan kompetensinya dan motivasi untuk selalu mengembangkan pembelajaran dengan menerapkan metode pembelajaran yang sesuai dan berkualitas dan salah satunya yaitu metode pembelajaran role playing.

\section{DAFTAR PUSTAKA}

Anas, S. (2009). Pengantar Statistik Pendidikan. Jakarta: PT. Raja Grafindo

Persada, Djamarah, SB. (2002). Prestasi Belajar dan Kompetensi Guru. Surabaya: Usaha Nasional

Gunawan, R. (2011). Pendidikan IPS Filosofi, Konsep dan Aplikasi. Bandung: Alfa Beta Hamdayama, J. (2016). Metodologi Pengajaran. Jakarta: PT. Bumi Aksara

Hamalik, O. (2004). Kurikulum dan Pembelajaran. Jakarta: PT. Bumi Aksara

Kunandar. (2013). Penelitian Tindakan Kelas. Jakarta: PT. Rajagrafindo Persada.

Kusumah, W \& Dwitagama, D. (2010). Mengenal Penelitian Tindakan Kelas. Jakarta: Permata Puri Media

Nur, A . (2006). Model Pembelajaran Cooperatif. Jakarta: Departemen Pendidikan Nasional

Sanjaya, W.(2013). Strategi Pembelajaran Berorientasi Standar Proses Pendidikan. Jakarta: Prenadamedia group

Sapriya. (2012). Pendidikan IPS Konsep dan Pembelajaran. Bandung: PT. Rosdakarya

Sugiyono. (2011) . Penelitian Pendidikan. Bandung: Alfabeta

Tu'u, T. (2004). Peran Disiplin Pada Perilaku dan Prestasi Belajar. Jakarta: PT. Gramedia Widisarana 